\title{
Cytogenotoxicity of shakes added with synthetic microingredients
}

\section{Citotoxicidade de diet shakes aditivados por microingredientes artificiais}

\author{
Débora Dayane Araujo Moura, Ana Paula Peron, Cleidiane Josefa dos Santos Veloso, Maria
}

Eduarda de Sousa Silva, Fabelina Karollyne Silva dos Santos, Valtânia Ana de Oliveira

Universidade Federal do Piauí, PI, Brasil

dayane.debora@hotmail.com; anapaulaperon@ufpi.edu.br; cleidiane8638@gmail.com; eduarda-sousa15@live.com; f.karolss@ hotmail.com; valtaniaoliveira@gmail.com

\begin{abstract}
The goal of this study was to evaluate the cytotoxicity and genotoxicity of diet shakes of three brands widely marketed in Brazil, named in this study of A, B and C. Assessments were carried out on root meristem cells of Allium cepa at exposure times 24 and 48 hours. The products (treatments) for $A$ and $B$ were evaluated at concentrations of $0.05 ; 0.10$ and $0.20 \mathrm{~g} / \mathrm{mL}$, and $C$ at the concentration 0.08; 0.16 and $0.32 \mathrm{~g} / \mathrm{mL}$. The diet products at the three concentrations tested, including those suggested as ideal for consumption by the manufacturers, at the two exposure times considered, were found to have significant antiproliferative effect on the meristems evaluated. However, none of the treatments caused significant cellular changes to the tissues of roots. Thus, the products tested were cytotoxic, but not genotoxic, to root meristem cells of $A$. cepa. Furthermore, it was observed that in all the treatments performed, in the three concentrations, the majority of the dividing cells were at prophase, not being observed cells at anaphase and telophase. Thus, it is suggested to conduct more in-depth studies on the cytotoxicity of these shakes in physiologically more complex bioassays for the verification and deepening of the data obtained here.
\end{abstract}

Keywords: Weight loss. Cell division. Cellular changes. Meristematic tissue.

\section{Resumo}

Objetivou-se na presente pesquisa avaliar a citotoxicidade e a genotoxicidade de diet shakes de três marcas amplamente comercializadas no Brasil, denominadas neste estudo de A, B e C. As avaliações foram realizadas em células meristemáticas de raizes de Allium cepa nos tempos de exposição 24 e 48 horas. Os produtos (tratamentos) referentes as marcas A e B foram avaliados nas concentrações 0,05; 0,10 e 0,20 g/mL, e C na concentração 0,08; 0,16 e 0,32 $\mathrm{g} / \mathrm{mL}$. Verificou-se que os produtos diet nas três concentrações, inclusive as sugeridas como ideais para consumo pelos fabricantes, nos dois tempos de análise considerados, causaram efeito antiproliferativo significativo aos meristemas as quais foram avaliadas. No entanto, nenhum dos tratamentos causou alterações celulares em número significativo aos tecidos das raizes. Assim, os produtos testados foram citotóxicos, porém, não genotóxicos, às células meristemáticas de raízes de A. cepa. Em todos os tratamentos realizados, nas três concentrações, a maioria das células em divisão encontrava-se em prófase, não se observando células em fase de anáfase e telófase. Dessa forma, sugere-se realizar estudos mais detalhados sobre a citotoxicidade destes shakes em bioensaios fisiologicamente mais complexos para a verificação e aprofundamento dos dados aqui obtidos.

Palavras-chave: Redutores de peso. Divisão celular. Alterações celulares. Tecido meristemático. 


\section{Introduction}

Brazil has experienced intense economic and social changes in its society in recent years, which has led to changes in its health and food model. These changes contributed to the reduction of poverty and social exclusion, but, on the other hand, led to an accelerated growth of overweight in individuals of different social classes (SOUSA; SILVA; BOULHOSA, 2016). With the increase in the incidence of obesity, there was a growing insertion of products in the Brazilian market regarded as potent weight reducers, among which we can mention the powder shakes.

Shakes are indicated to replace one or two daily meals, and are sold without restrictions in drugstores all over the country (CAVICHIOLI; ABOURIHAN; PASSONI, 2012). They are classified as diet foods because they have a balanced composition of vitamins, minerals, dietary fibers, and reduced amounts of carbohydrates and fatty acids, in order to supply the nutritional needs of the individual basically and in a balanced way (ARAÚJO; FORTES; FAZZIO, 2013). In Brazil, diet foods are generally standardized and authorized for consumption and commercialization by the National Health Surveillance Agency (ANVISA), through Ordinance 30 as of December 13, 1998, which approves the Regulation on foods for weight control (BRASIL, 1998).

However, diet shakes are also classified as industrialized foods because they are added with synthetic microingredients of flavor, coloring, anti-wetting, thickener, emulsifier and sweetener classes (SOUSA et al., 2016). The addition of these microingredients, among other characteristics, has the purpose of promoting total dilution of the powder, which results in the homogeneous appearance of the product when dissolved in water or milk, as well as reducing significantly the absorption capacity of air humidity or hygroscopic capacity of the shake during storage and once opened for consumption. They also soften the taste, smell and color of this food making it more attractive to the consumer. However, researchers such as Tonetto et al. (2008), Sardi et al. (2010), Carvalho et al. (2017) and ANVISA (BRASIL, 2007) state that many food additives, such as flavoring, coloring, anti-wetting, thickener, emulsifiers and sweeteners, among others, raise doubts about their potential cytotoxic, genotoxic, mutagenic and carcinogenic effects.

Thus, it is necessary to carry out studies that, through appropriate bioassays, evaluate the cellular toxicity of industrialized products, such as diet shakes, in order to properly provide the well-being of consumers. According to Brasil (2007) and Sales et al. (2017), toxicological analysis on food additives and, especially, foods containing such compounds, are the basis for elaboration or modification of the documents that standardize the basic composition of foods and/or semi-industrialized and industrialized products. However, to date, there are no studies evaluating the toxicity of diet shakes in the scientific literature at national and international level.

The root meristem of Allium cepa L. (onion) is considered in the scientific milieu as an efficient bioassay for the evaluation of the acute toxicity at the cellular level of chemical compounds due to the reduced chromosome number $(2 \mathrm{n}=16)$, which favors detection of chromosomal or clastogenic alterations, mitotic spindle disturbances or aneugenic alterations, and disorders in the cell proliferation index. This test system is internationally accepted by research agencies as an assessment tool with accurate sensitivity for analysis of cytotoxicity, genotoxicity and mutagenicity of the substance of interest, since the results achieved demonstrate, in most cases, satisfactory similarity to those obtained though animal testing systems and in cell cultures (HERRERO et al., 2011; NEVES et al., 2014; LACERDA; MALAQUIAS; PERON, 2014; TABREZ et al., 2011; GOMES et al., 2013; OLIVEIRA et al., 2013; CAMPOS; MARIN-MORALES, 2016; MOURA et al., 2016; SANTANA et al., 2016).

Therefore, the goal of this study was to evaluate the cytotoxicity and genotoxicity of diet shakes in root meristem cells of A. cepa, from three different highly commercialized brands in drugstores all over Brazil.

\section{Material and Methods}

Diet shakes products from three different brands, referred to in this study as A, B and C, were purchased at a drugstore located in the municipality of Picos, State of Piauí, Brazil, in November 2016. The samples obtained were within the shelf life.

Shakes evaluated in this work are marketed in powder form. To determine the concentrations to be analyzed as for toxicity at the cellular level, the form of preparation and ingestion indicated on the labels of each product was used as a parameter. Thus, brands A and B suggested to dilute $30 \mathrm{~g}$ of the product in $300 \mathrm{~mL}$ water. Based on this information, we set the concentrations of $0.05 ; 0.10$ and $0.20 \mathrm{~g} / \mathrm{mL}$ for these shakes. Brand $\mathrm{C}$, it was recommended to dilute $40 \mathrm{~g}$ of shake powder in $250 \mathrm{~mL}$ water, and then we set the concentrations of $0.08 ; 0.16$ and $0.32 \mathrm{~g} / \mathrm{mL}$. To prepare all concentrations, distilled water was used.

For toxicity assessment, initially, onion bulbs - purchased in an organic garden located in the city of Picos, Piauí, Brazil - were allowed to root in bottles with distilled water, at room temperature $\left( \pm 27^{\circ} \mathrm{C}\right)$, until the roots were $2.0 \mathrm{~cm}$ in length. For analysis of each diet shake sample, an experimental group with five onion bulbs was established. Before placing the roots in contact with their respective samples (treatments), some roots were collected and fixed to serve as control of the bulb itself. Then, the remaining roots were placed into their respective treatments for 24 hours, a procedure called 24-hour exposure time. After 24 hours, some roots were collected and fixed. After this procedure, the remaining roots of each bulb were returned to 
their respective treatments where they remained for additional 24 hours, which was called 48-hour exposure time. Next, roots were again taken and fixed. The 24- and 48-hour exposure times were chosen with the purpose of evaluating the action of milk diluted in more than one cell cycle. Roots were fixed in Farmer 3: 1 (ethanol: acetic acid) for 24 hours. In each collection, on average, three roots were taken per bulb.

The slides, on average 03 per bulb, were mounted according to Guerra and Souza (2002), and analyzed under an optical microscope using 40x objective lens. For each onion bulb, we analyzed 1000 cells, totaling 5000 cells for each control, 24hour exposure time and 48-hour exposure time of each treatment group under analysis. Thus, for each brand of diet shake, we analyzed a total of 15000 cells. Cells were observed in interphase, prophase, metaphase, anaphase and telophase. From this analysis, the mitotic index (MI) was determined by means of the following equation: $\mathrm{MI}=($ total number of cells in mitosis $\div$ total number of cells analyzed) x 100 . The MI value was a parameter used for the determination of the cytotoxic potential of the samples of diet shakes under study. The experiments were developed in the Laboratório de Citogenética e Mutagênese (LaCM), of the Campus Senador Helvídio Nunes de Barros (CSHNB) of Universidade Federal do Piauí (UFPI).

We also evaluated the genotoxic potential of concentrations of diet shakes by the frequency of micronucleated cells, colchicine metaphases, anaphase and telophase bridges, cells with adhesion, nuclear buds and multipolar anaphases. The statistical analysis of data was performed by Chi-square test $\left(\chi^{2}\right), p<0.05$, using the software BioEstat 3.0 (Ayres, Ayres, \& Ayres, 2007). Toxicity tests were carried out in duplicate to validate the results obtained.

\section{Results and discussion}

From the results in Table 1, it can be seen that all diet products, at the three concentrations and in the two exposure times considered, caused significant inhibition of cell division in the root meristems. Such a condition can be evidenced by comparing the mitotic indices obtained for the times 24-hour and/or 48-hour of A, B, C to the cell division index observed for their respective controls. However, when the cell division indices were compared between the exposure times 24 and 48 hours of the same treatment, they were not significantly different from each other for any of the diet shakes evaluated. Still in Table 1 , it can be observed that in all the treatments performed, the majority of the cells in division are in prophase. No anaphase and telophase cells were observed in the meristems treated with the diet products.

Table 1 - Number of cells observed in each phase of the cell cycle of the root meristem tissue of Allium cepa of the three chemical laboratories referred to in the table as A, B and C exposed for 24 and 48 hours to shake diets. The concentrations analyzed for A and B were $0.05 ; 0.10$ and $0.20 \mathrm{~g} / \mathrm{mL}$, and for B 0,$08 ; 0,16$ and $0,32 \mathrm{~g} / \mathrm{mL}$.

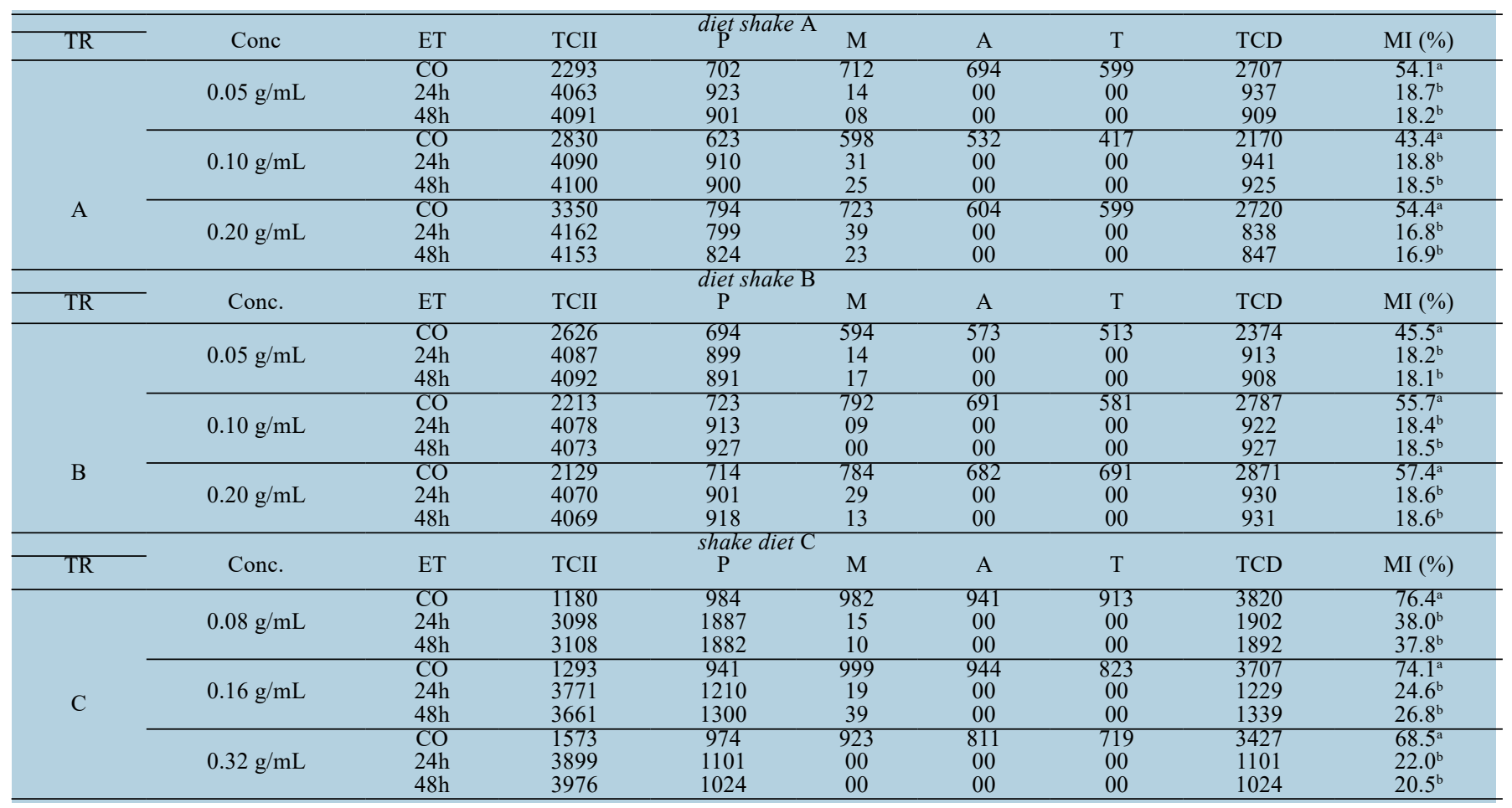

TCII - Total number of cells in interphase and undifferentiated cells; ET - Exposure Time; CO - Control; MI - Mitotic Index; P - Prophase; M Metaphase; A - Anaphase; T - Telophase; TCD - Total number of dividing cells. TAC - Total Cellular Alterations. MI values followed by different letters within the same treatment are significantly different by $\chi^{2}$ test, at $5 \%$. 
The cytotoxic potential of industrialized products, such as the diet shakes evaluated here, can be determined by the increase or decrease in the mitotic index of cells of the tissues exposed to them (FERNANDES et al., 2007; CARVALHO et al., 2017). According to Caritá and Marin-Morales (2008), cell division indices below the negative control, when considered significant, indicate the presence of agents whose toxic action impairs the growth and development of organisms subjected to these substances. In addition, Gomes et al. (2013), Sales et al. (2016) and Moura et al. (2016) argue that the inhibition of cell proliferation triggered by cytotoxic compounds in tissues of intense cell proliferation and normal performance and/or no cell changes - such as the root meristems used herein to assess the toxicity of diet shakes - is extremely harmful to the organism, since it has the property of inhibiting or limiting the replacement of cells, altering the protein synthesis and, consequently, resulting in malfunction of the organ where it is located.

According to Marques et al. (2014), chemical agents present in the formulation of foods or industrialized products may inhibit the formation of the mitotic spindle in tissues of intense cellular proliferation. This can lead to two situations: the first would be the formation of polyploid cells at the end of cell division, giving rise to a tissue with aberrant cells. The other, and the most indicated to explain the result observed in the present study, is that the polyploid cells produced were eliminated from the root meristems exposed to the diet products evaluated, once the principle of the cell cycle is the formation of identical cells, and the presence of cells with great variation in the chromosome number would make cell functioning, and of the tissue itself, impracticable. Moreover, the evaluated diet products did not induce alterations in the mitotic spindle in the root tissues at a statistically significant frequency.

As mentioned earlier, the formulation of diet shakes contains food additives of different classes. Although scarce, there are studies in the scientific literature that show that some of these microingredients have the potential to cause toxicity at the cellular level. Among the sweetening additives cited on the labels of the diet products evaluated in the present study are sucralose, sodium cyclamate and aspartame. In a study by Van EyK et al. (2015), through normal cell lines, Caco-2 (colon cells), HT-29 (colon cells) and HEK-293 (kidney cells), it can be verified that these food additives were cytogenotoxic to these bioassays at different times of analysis. Furthermore, Sasaky et al. (2002), using the comet bioassay, verified that sodium cyclamate was cytogenotoxic and clastogenic to the colon of rodents chronically treated via gavage with this microingredient. As for the anti -wetting agent used in the diet shakes formulation, the only one mentioned on the label of the products in question was silicon dioxide. Rajiv et al. (2016) reported that this additive drastically reduced cell division and induced a significant frequency of cellular alterations in human lymphocytes in culture of normal cells.

In relation to flavorings, the aroma and flavor ingredients mentioned on the labels of the diet products evaluated herein were those of chocolate and vanilla. Sales et al. (2017) and Silva et al. (2016) evaluated these flavorings in root meristem cells of $A$. серa and verified that these additives, at all doses and times of analysis considered, drastically reduced the cell division of the tissues analyzed, being potentially cytotoxic. Gultekin et al. (2013) observed that these flavorings had the property of inducing significant damage to the mitotic spindle, and, consequently, the cellular division of premature erythrocytes of mice, expressively inducing the formation of micronucleated cells in the bone marrow of these animals.

Also, according to ANVISA, food flavorings in general contain the chemical compounds diacetyl (2,3-butadione), whose main function is to fix the aroma and flavor in industrialized foods. Whittaker et al. (2008) evaluated the mutagenic potential of this chemical in a gene mutation assay using mouse lymphoma cells, line L5178Y, and found that diacetyl caused significant damage to the chromosome 11 loci of these cells. It also caused the functional loss of the locus of thymidine kinase enzyme in these animals. Further, More, Raza and Vince (2012) reported that high concentrations of diacetyl are mutagenic and have the potential to replace thymine with guanine. This shift has the property of breaking the hydrogen and disulfide bonds of the tertiary structure of proteins, such as those involved in cell division.

Thus, the results of cell-level toxicity investigations in the scientific literatures, anti-wetting and flavoring additives corroborate with the results obtained here with diet shakes. There were no studies evaluating the toxicity, at the systemic and cellular level, of food additives of thickening, emulsifying and stabilizing action in general. The coloring mentioned on the label of the three diet products evaluated was caramel. Studies assessing the toxicity of this specific additive showed that it was not cytotoxic, genotoxic and mutagenic to the bioassays to which it was analyzed (SENGAR; SHARMa, 2014; KRISHNA; GOEL; KRISHNA, 2014).

Therefore, the observed results showed that the diet shakes analyzed had significant potential of causing toxicity to root meristem cells of A. серa. This result indicates that these foods should be evaluated in physiologically more complex bioassays, such as in animal testing systems, to validate and deepen the data obtained here, so as to guarantee the safety of consumers.

\section{Conclusion}

The diet shakes evaluated were cytotoxic, but not genotoxic to root meristem cells of $A$. cepa. It is suggested that the three evaluated products interfered with the formation of the mitotic spindle of the cells of the tissues exposed to them, not allowing the cells to progress to anaphase. 


\section{References}

ARAÚJO, L. M. P.; FORTES, R. C.; FAZZIO, D. M. G. Análise do uso de dietas da moda por indivíduos com excesso de peso. Journal Health Science Institute, v. 31, n. 4, p. 388-391, 2013.

AYRES, M.; AYRES, J. R. M.; AYRES. D. L.; SANTOS, A. S. BioEstat 5.0 - Aplicações Estatísticas nas Áreas das Ciências Biológicas e Médicas. Brasília: CNPq, 2007.

BRASIL. Agência Nacional de Vigilância Sanitária (BR). Portaria no 30, de 13 de janeiro de 1998, que aprova o Regulamento Técnico referente a Alimentos para Controle de Peso. Brasília, DF: ANVISA.

CARITÁ, R.; MARIN-MORALES, M. A. Induction of chromosome aberrations in the Allium cepa test system caused by the exposure of seeds to industrial effluents contaminated with azo dyes. Chemosphere, v. 72, n. 5, p. $722-725,2008$.

CARVALHO, F. R.; MOURA, A. G.; RODRIGUES, G. F.; NUNES, N. M.; LIMA, D. J.; PESSOA, C.; PERON, A. P. Are salty liquid food flavorings in vitro antitumor substances? Anais da Academia Brasileira de Ciências, v. 88, n. 3, p. 1419-1430, 2016.

CARVALHO, B. D. L.; SALES, I. M. S.; PERON A. P. Cytotoxic, genotoxic and mutagenic potential of UHT whole milk. Ciência e Tecnologia de Alimentos (Campinas), v. 37, n. 2, p. 275-279, 2017.

CAVICHIOLI, B.; ABOURIHAN, C. L. S.; PASSONI, C. M. S. Monitoramento da administração de um suplemento como coadjuvante na perda de peso. Saúde, v. 1, n. 1, p. 90-110, 2012.

FERNANDES, T. C. C.; MAZZEO, D. E. C.; MARIN-MORALES, M. A. Mechanism of micronuclei formation in polyploidizated cells of $A$. cepa exposed to trifluralin herbicide. Pesticide Biochemistry and Physiology, v. 88, n. 3, p. 252-259, 2007.

GOMES, K. M. S.; OLIVEIRA, M. V. G. A. D.; CARVALHO, F. R. D. S.; MENEZES, C. C.; PERON, A. P. Citotoxicity of food dyes sunset yellow (E-110), bordeaux red (E-123), and tatrazine yellow (E-102) on Allium серa L. root meristematic cells. Ciência e Tecnologia de Alimentos (Campinas), v. 3, n. 1, p. 218-223, 2013.

GUERRA, M.; SOUZA, M. J. Como observar os cromossomos: um guia de técnicas em citogenética vegetal, animal e humana. Ribeirão Preto: FUNPEC.

GULTEKIN, F.; DOGUC, D. K.; KULAC, E. Effects of maternally exposed coloring food additivies on receptor expressions related to learning and memory in rats. Food Chemical and Toxicology, v. 56, p. 145-148, 2012.

HERRERO, O.; MARTÍN, J. P; FREIRE, P. F; LÓPEZ, L. C.; PEROPADRE, A.; HAZEN, M. J. Toxicological evaluation of three contaminant of emerging concern by use of Allium cepa test. Mutation Research, v. 743, $\mathrm{n}$. 1-2, p. 24-34, 2012.

KRISHNA, K. A.; GOEL, S.; KRISHNA G. S. A. R. Genotoxicity and tumorigenicity predictions for 2-MI and 4-MI using multiple SAR software. Toxicology Mechanisms and Methods, v. 24, n. 4, p. 284-293, 2014.

LACERDA, L. P.; MALAQUIAS, G.; PERON, A.P. Antiproliferative action of aqueous extracts of Hymenaea stigonocarpa Mart. (Fabaceae) on the cell cycle of Allium cepa L. Anais da Academia Brasileira de Ciências, v. 89, n. 3, p. 1147-1150, 2014.

MARQUES, G.; DANTAS, E. B. S.; LIMA, L. H. G. M.; PERON, A. P. Ação do suco do fruto de Morinda citrifolia L. em células de sistema-teste vegetal. Biotemas, v. 27, n. 1, p. 43-146, 2015.

MORE, S. S.; RAZA, A.; VINCE, R. The butter flavorant, diacetyl, forms a covalent adduct with 2-deoxyguanosine, uncoils DNA, and leads to cell death. Journal of Agricultural of Food Chemistry, v. 60, n. 12, p. 3311-3317, 2012. 
MOURA, A. G.; SANTANA, G. M.; FERREIRA, P. M. P.; SOUSA, J. M. C.; PERON, A. P. (2016). Cytotoxicity of Cheese and Cheddar Cheese food flavorings on Allim cepa L. root meristems. Brazilian Journal of Biology, v. 76, n. 2, p. 439-443, 2016.

NEVES, E. S.; FERREIRA, P. M. P.; LIMA, L. H. G. M.; PERON, A. P. Action of aqueous extracts of Phyllanthus niruri L.(Euphorbiaceae) leaves on meristematic root cells of Allium cepa L. Anais da Academia Brasileira de Ciências, v. 86, n. 3, p. 1131-1137, 2014.

OLIVEIRA, M. V. A.; ALVES, D. D. L.; LIMA, L. H. G. M.; CASTRO, J. M.; PERON, A. P. Cytotoxicity of erythrosine food colors (E-127), bright blue (E-133) and red 40 (E-129) In plant test system. Acta Scientiarum. Biological Science, v. 35, n. 1, p. 557-562, 2013.

RAJIV, S.; JEROBIN, J.; SARANYA, U.; NAINANAT, M.; SHARMA, A.; MARWANA, P.; MUKHERJEE A. Comparative cytotoxicity and genotoxicity of cobalt (II, III) oxide, iron (III) oxide, silicon dioxide, and aluminum oxide nanoparticles on human lymphocytes in vitro. Human \& Experimental Toxicology, v. 35, n. 2, p. 170-18, 2016.

SALES, I. M. S.; SANTOS, F. K. S.; SILVA, F. C. C.; SOUSA, J. M. C.; PERON, A. P. Acute Toxicity of Grape, Plum and Orange Synthetic Food Flavourings Evaluated in in vivo Test Systems. Food Technology and Biotechnology, v. 55, n. 1, p. 131-137, 2017.

SANTANA, G. M.; DEUS, M. S. M.; SOUSA, J. M. C.; FERREIRA, P. M. P.; FERNANDES, H. B.; PERON, A. P. Antimitotic and antimutagenic action of the Hymenaea stigonocarpa bark on dividing cells. Brazilian Journal of Biology, v. 76, n. 1, p. 520-525, 2016.

SARDI, M.; HALDEMANN, H.; NORDMANN, B.; BOTTEX, B.; SAFFORD, B.; SMITH, B.; TENNANT, D.; HOWLETT, J.; JASTI, P. R. (2010). Use of retailer fidelity card schemes in the assessment of food additive intake: sunset yellow a case study. Food Additives and Contaminants Part A, v. 27, n. 11, p. 1507-1515, 2010.

SASAKI, Y. F.; KAWAGUCHI, S.; KAMAYA, A.; OHSHITA, M.; KABASAWA, K.; IWAMA, K.; TSUDA, S. The comet assay with 8 mouse organs: results with 39 currently used food additives. Mutation Research, v. 519, n. 1, p. 103-119, 2002.

SENGAR, G.; SHARMA, H. K. Food caramels: a review. Journal of Food Science and Technology, v. 51, n. 9, 1686-1696, 2014.

SILVA, S. I. O.; SANTANA, G. M.; SALES, I. M. S.; SOUSA, J. M. C.; PERON, A. P. Toxicity in food flavoring at the cellular level associated with each other at diferente doses. Acta Scientiarum. Biological Science, v. 38, n. 1, p. 77-84, 2016.

SOUSA, L. C.; SILVA, N. A.; BOULHOSA, R. B. Avaliação da composição nutricional através da rotulagem de shakes utilizados como substitutos de refeições. Revista Eletrônica Estácio Saúde, v. 5, n. 2, p. 78-90, 2016.

TABREZ, S.; SAHKIL, S.; UROOJ, M.; DAMANHORI, G. A.; ABUZENADAH, A. M.; AHMAD, D. Genotoxicity testing and biomarker studies on surface water: an over view of the techniques and their efficacies. Journal of Environmental Science and Health Part A, v. 29, n. 3, p. 250-257, 2011.

TONETTO, A.; HUANG, A.; YOKO. J.; GONÇALVES, R. O uso de aditivos de cor e sabor em produtos alimentícios. São Paulo: Faculdade de Ciências Farmacêuticas, 2008.

VAN EYK A. D. The effect of five artificial sweeteners on Caco-2, HT-29 and HEK-293 cells. Drug Chemical and Toxicology, v. 38, n. 3, p. 318-327, 2015.

WHITTAKER, P.; CLARKE, J. J.; SAN, R. H.; BEGLEY, T. H.; DUNKEL, V. C. Evaluation of the butter flavoring chemical diacetyl and a fluorochemical paper additive for mutagenicity and toxicity using the mammalian cell gene mutation assay in L5178Y mouse lymphoma cells. Food Chemical and Toxicology, v. 46, n. 8, p. 928-2933, 2008. 